\title{
Perilaku Pemeliharaan dan Status Kebersihan Gigi dan Mulut Masyarakat di Kelurahan Paniki Kabupaten Sitaro
}

\author{
${ }^{1}$ Fitri K. Wulandari \\ ${ }^{2}$ Damajanty H. C. Pangemanan \\ ${ }^{1}$ Christy N. Mintjelungan \\ ${ }^{1}$ Program Studi Pendidikan Dokter Gigi Fakultas Kedokteran \\ ${ }^{2}$ Bagian Fisiologi Fakultas Kedokteran \\ Universitas Sam Ratulangi Manado \\ E-mail: fitrikusumawulandari@gmail.com
}

\begin{abstract}
Oral health plays an important role in the body health status. This study was aimed to determine the behavior about dental and oral health care among the people at Paniki, Sitaro. This was a descriptive study with a cross sectional design. Population consisted of people living at Paniki, Sitaro aged 18-60 years. There were 92 respondents obtained by using purposive sampling method. Data were collected by using questionnaire and examination of simplified oral hygiene index (OHI-S). The results showed that $60.8 \%$ of respondents had good behavior of dental and oral health care, and $75 \%$ of respondents had OHI-S evaluation as poor category. Conclusion: In general, people of Paniki, Sitaro had good behavior about dental and oral health care but their dental and oral hygiene was in poor category.
\end{abstract}

Keywords: behavior of dental and oral hygiene maintenance

\begin{abstract}
Abstrak: Kesehatan gigi dan mulut berperan penting bagi kesehatan tubuh umumnya. Penelitian ini bertujuan untuk mengetahui perilaku pemeliharaan dan status kebersihan gigi dan mulut masyarakat di Kelurahan Paniki Kabupaten Sitaro. Jenis penelitian ialah deskriptif dengan desain potong lintang, dilakukan terhadap masyarakat usia 18-60 tahun di Kelurahan Paniki Kabupaten Sitaro. Jumlah responden 92 orang diperoleh dengan menggunakan metode purposive sampling. Pengumpulan data didapat melalui pengisian kuisioner dan pemeriksaan Oral Hygiene Index Simplified (OHI-S). Hasil penelitian menunjukkan bahwa perilaku pemeliharaan kesehatan gigi dan mulut masyarakat di Kelurahan Paniki Kabupaten Sitaro sebanyak 60,8\% tergolong baik. Penilaian OHI-S dari masyarakat Paniki sebanyak 75\% tergolong buruk. Simpulan: Pengetahuan, sikap, dan tindakan masyarakat di Kelurahan Paniki Kabupaten Sitaro tergolong baik tetapi status kebersihan gigi dan mulut tergolong buruk.
\end{abstract}

Kata kunci: Perilaku pemeliharaan kebersihan gigi dan mulut

Kesehatan gigi dan mulut ialah salah satu faktor yang mendukung paradigma sehat dan merupakan strategi pembangunan nasional untuk mewujudkan pembangunan kesehatan bagi sumber daya manusia yang produktif secara sosial dan ekonomi; oleh karena itu setiap orang harus memiliki kesadaran, kemauan, dan kemampuan untuk meningkatkan kesehatan yang setinggi-tingginya. ${ }^{1}$ Kesehatan gigi dan mulut merupakan bagian dari kesehatan tubuh yang tidak dapat dipisahkan satu dan lainnya karena akan memengaruhi kesehatan tubuh secara keseluruhan. ${ }^{2}$ Pengetahuan tentang kesehatan gigi dan mulut sangat penting untuk terbentuknya tindakan menjaga kebersihan gigi dan mulut. ${ }^{3}$ Berdasarkan Undang-Undang Kesehatan 
nomor 36 tahun 2009, yaitu memelihara dan meningkatkan derajat kesehatan masyarakat dalam bentuk peningkatan kesehatan gigi, pengobatan penyakit gigi, dan dilaksanakan melalui pelayanan kesehatan gigi masyarakat. ${ }^{1}$

Kesehatan tubuh secara keseluruhan banyak dipengaruhi oleh gigi dan mulut. Salah satu fungsi gigi yaitu sebagai alat pengunyah makanan, membantu melumatkan makanan dalam mulut guna membantu organ pencernaan sehingga makanan dapat diserap tubuh dengan baik. ${ }^{1}$

Menurut Notoadmodjo, ${ }^{4}$ salah satu hal yang dapat memengaruhi derajat kesehatan seseorang termasuk kesehatan gigi dan mulut yaitu perilaku. Domain perilaku kesehatan terbagi atas tiga yaitu pengetahuan, sikap, dan tindakan. McDonald dan Avery $^{5}$ mengemukakan bahwa penyakit gigi dan mulut saat ini sangat dipengaruhi oleh beberapa faktor antara lain pengetahuan dan sikap atau perilaku masyarakat mengenai pentingnya perawatan dan pemeliharaan kesehatan gigi dan mulut.

Riset Kesehatan Dasar (Riskesdas) tahun $2013^{6}$ memperlihatkan prevalensi penduduk di Sulawesi Utara yang bermasalah dengan gigi dan mulut lebih tinggi dibandingkan prevalensi penduduk di Indonesia yang bermasalah dengan gigi dan mulut $(25,9 \%)$, yaitu sebesar $31,6 \%$, sedangkan yang menerima perawatan dari tenaga medis gigi di Sulawesi Utara lebih sedikit dibandingkan dengan di Indonesia $(31,1 \%)$, yaitu sebesar $25,1 \%$. Hal ini menunjukkan bahwa masalah kesehatan gigi dan mulut di Sulawesi Utara masih sangat tinggi dan tidak semua masalah kebersihan gigi dan mulut mendapatkan perawatan dari tenaga medis gigi. ${ }^{7}$

Kelurahan Paniki merupakan salah satu kelurahan yang terletak di Kabupaten Sitaro Sulawesi Utara. Berdasarkan survei awal sebagian besar masyarakat masih kurang memerdulikan masalah kesehatan gigi dan mulut. Berdasarkan latar belakang tersebut, peneliti tertarik untuk melakukan penelitian tentang perilaku pemeliharaan dan status kesehatan gigi dan mulut masyarakat di Kelurahan Paniki Kabupaten Sitaro.

\section{BAHAN DAN METODE PENELITIAN}

Jenis penelitian ini ialah deskriptif dengan desain potong lintang yang dilaksanakan di Kelurahan Paniki Kabupaten Sitaro pada bulan Juli 2016.

Penelitian dilakukan dari rumah ke rumah sambil membagikan surat persetujuan menjadi subjek penelitian (informed consent) yang ditanda tangani subjek penelitian didampingi peneliti. Tingkat pengetahuan diperoleh melalui kuesioner. Indeks kebersihan gigi dan mulut diperoleh dengan mengukur tingkat kebersihan mulut dan dilakukan penilaian (skoring). Hasil penelitian dicatat pada lembar pemeriksaan OHI-S. Tingkat keber-sihan rongga mulut dinilai menggunakan Oral Hygiene Index Simplified (OHI-S). Kriteria ini berdasarkan keadaan endapan lunak atau debris dan karang gigi kalkulus. Pemeriksaan pada 6 gigi yaitu gigi 16, 11, 26, 36, 31, dan 46 . Pada gigi 16, 11, 26, 31, yang dilihat permukaan bukalnya sedang-kan gigi 36 dan 46 permukaan lingualnya. Indek debris yang dipakai ialah Debris Index (DI) Green and Vermillion (1964). ${ }^{8}$

Kriteria penilaian debris mengikuti ketentuan sebagai berikut.

Debris index $=$ Jumlah penilaian debris

$$
\text { Jumlah gigi yang diperiksa }
$$

Penilaian debris score dan calculus score ialah sebagai berikut: ${ }^{8}$

a. Baik, bila nilai berada diantara $0-0,6$

b. Sedang, bila nilai berada diantara $0,7-1,8$

c. Buruk, bila nilai berada diantara 1,9-3,0

Indeks kalkulus yang digunakan ialah:

0 . Tidak ada kalkulus atau karang gigi

1. Kalkulus supragingival menutupi permukaan gigi kurang dari $1 / 3$ permukaan gigi.

2. Kalkulus supragingival menutupi permukaan gigi lebih dari $1 / 3$ tetapi tidk lebih dari $2 / 3$ permukaan gigi.

3. Kalkulus supragingival menutupi permukaan gigi lebih dari $2 / 3$

Penilaian calculus score ialah sebagai beriku

a. Baik, bila nilai berada diantara $0-0,6$

b. Sedang, bila nilai berada diantara $0,7-1,8$

c. Buruk, bila nilai berada diantara 1,9-3,0 
Penghitungan OHI-S dilakukan sebagai berikut: $\mathrm{OHI}-\mathrm{S}=$ Debris index + Calculus index

\section{HASIL PENELITIAN}

Penelitian ini dilakukan di Kelurahan Paniki Kabupaten Sitaro Sulawesi Utara. Populasi penelitian sebanyak 1.162 orang. Sampel minimal ditentukan dengan menggunakan rumus Slovin, dan diperoleh sebanyak 92 orang. Distribusi responden berdasarkan jenis kelamin memperlihatkan persentase yang lebih tinggi pada kelompok perempuan $(52,17 \%)$ (Tabel 1).

Tabel 1. Distribusi responden menurut jenis kelamin

\begin{tabular}{ccc}
\hline Jenis kelamin & n & \% \\
\hline Laki-laki & 44 & 47,83 \\
Perempuan & 48 & 52,17 \\
Total & 92 & 100 \\
\hline
\end{tabular}

Distribusi responden berdasarkan usia yang terbanyak yaitu usia 40-50 tahun $(33,70 \%)$ dan yang paling sedikit pada usia 29-39 tahun (17,39\%) (Tabel 2).

Tabel 2. Distribusi responden berdasarkan usia

\begin{tabular}{ccc}
\hline Kelompok usia & n & \% \\
\hline $18-28$ & 26 & 28,26 \\
$29-39$ & 16 & 17,39 \\
$40-50$ & 31 & 33,70 \\
$51-60$ & 19 & 20,65 \\
Total & 92 & 100 \\
\hline
\end{tabular}

Distribusi perilaku responden berdasarkan pengetahuan sebanyak 56 orang $(60,86 \%)$ dengan pengetahuan baik dan 36 orang dengan pengetahuan tidak baik $(39,13 \%)$ (Tabel 3).

Tabel 3. Distribusi perilaku responden berdasarkan pengetahuan

\begin{tabular}{ccc}
\hline Pengetahuan & n & \% \\
\hline Baik & 56 & 60,86 \\
Tidak baik & 36 & 39,13 \\
Total & 92 & 100 \\
\hline
\end{tabular}

Pada distribusi perilaku responden berdasarkan sikap terdapat 75 orang
$(81,52 \%)$ dengan sikap yang baik, lebih tinggi dibandingkan dengan yang tidak baik yaitu 17 orang $(18,48 \%)$ (Tabel 4$)$.

Tabel 4. Distribusi perilaku responden berdasarkan sikap

\begin{tabular}{ccc}
\hline Sikap & n & \% \\
\hline Baik & 75 & 81,52 \\
Tidak baik & 17 & 18,48 \\
Total & 92 & 100 \\
\hline
\end{tabular}

Distribusi perilaku responden berdasarkan tindakan baik yaitu 55 orang $(59,78 \%)$ sedangkan yang tidak baik 37 orang $(40,22 \%)$ (Tabel 5).

Tabel 5. Distribusi perilaku responden berdasarkan tindakan

\begin{tabular}{ccc}
\hline Tindakan & n & \% \\
\hline Baik & 55 & 59,78 \\
Tidak baik & 37 & 40,11 \\
Total & 92 & 100 \\
\hline
\end{tabular}

Distribusi pemeliharaan status kebersihan gigi dan mulut memperlihatkan sebagian besar responden tergolong buruk yaitu sebanyak 69 orang $(75 \%)$.

Tabel 6. Distribusi responden berdasarkan pemeliharaan status kebersihan gigi dan mulut

\begin{tabular}{ccc}
\hline Status OHI-S & N & \% \\
\hline Baik & 0 & 0 \\
Sedang & 23 & 25 \\
Buruk & 69 & 75 \\
Total & 92 & 100 \\
\hline
\end{tabular}

\section{BAHASAN}

Penelitian ini dilakukan di Kelurahan Paniki Kabupaten Sitaro untuk mengetahui perilaku pengetahuan masyarakat serta status kebersihan gigi dan mulut masyarakat.

Berdasarkan hasil penelitian tingkat pengetahuan masyarakat sebagian besar tergolong baik (Tabel 5). Hal ini dikarenakan adanya faktor-faktor yang mendukung, yaitu adanya akses informasi yang sudah tersedia melalui berbagai media seperti televisi, internet, komputer dan lain-lain. Selain itu sudah tersedianya pelayanan 
kesehatan seperti puskesmas, dan status sosial ekonomi masyarkat di Kelurahan Paniki tergolong baik. Hal ini sejalan dengan penelitian Sahi (2014), yang mengemukakan bahwa faktor-faktor tersebut memengaruhi tingkat pengetahuan. ${ }^{8}$

Berdasarkan usia responden, masyarakat terbanyak berusia $40-50 \quad(33,70 \%)$. Seiring pertambahan usia mengindikasikan bahwa perilaku cenderung menjadi lebih baik ketika usia bertambah. Hal ini sesuai dengan teori yang dikemukakan Soekidjo bahwa semakin bertambah usia, maka pengetahuan yang akan didapat semakin banyak, diiringi dengan perkembangan mental yang lebih baik sehingga motivasi untuk berperilaku baik menjadi lebih besar. ${ }^{8}$ Penelitian McIntosh et al. ${ }^{9}$ menunjukkan bahwa seiring penambahan usia, maturasi otak meningkat dan membuat seseorang akan memiliki perilaku yang cenderung tepat dan tidak lagi berada dalam tahap coba-mencoba terhadap sesuatu. Usia yang semakin dewasa akan lebih mudah memberikan tanggapan yang diperoleh baik melalui pendidikan maupun pengalaman-pengalaman.

Distribusi pengetahuan dengan kategori baik terdapat sebanyak 56 orang $(60,86 \%)$, sedangkan yang berpengetahuan tidak baik 35 orang $(39,13 \%)$. Distribusi sikap responden juga tergolong baik $(81,52 \%)$ dibandingkan dengan yang tidak baik $(18,48 \%)$. Demikian halnya dengan tindakan responden yang tergolong baik 55 orang $(59,78 \%)$, sedangkan yang kategori tidak baik 37 orang $(40,22 \%)$.

Distribusi kategori perilaku baik berdasarkan jenis kelamin menunjukkan $52,17 \%$ pada kelompok perempuan berperilaku baik sedangkan pada kelompok lakilaki terdapat sebanyak 47,83\%. Dengan demikian, perilaku pemeliharaan kesehatan gigi dan mulut kategori baik lebih tinggi terdapat pada kelompok perempuan. Terdapat beberapa faktor yang memengaruhi pengetahuan seseorang yaitu faktor yang berasal dari diri sendiri (pendidikan, motivasi, dan persepsi), serta faktor yang berasal dari luar (informasi, sosial, budaya dan lingkungan). Informasi tidak hanya bersifat formal, tetapi banyak sumber informasi lain yang bisa didapatkan yaitu dari media cetak dan elektronik. Semakin banyak informasi yang didapatkan, maka semakin tinggi pengetahuan seseorang tentang suatu hal. ${ }^{10}$

Pada penelitian ini, walaupun sebagian besar perilaku masyarakat Kelurahan Paniki tergolong baik, OHI-S dari masyarakat sebagian besar tergolong buruk. Hasil penelitian ini sejalan dengan penelitian oleh Rosdewati $^{11}$ yang melakukan penelitian survei dengan pendekatan deskriptif analitik melalui startified rendom sampling terhadap sebanyak 345 siswa SMA di Kabupaten Langkat. Siswa diberikan kuesioner dan dilakukan pemeri-ksaan terhadap gigi dan mulut. Uji chi-square terhadap perilaku siswa terdiri dari faktor pengetahuan, sikap dan tindakan dengan status kesehatan gigi dan mulut berdasarkan indikator usia 18 tahun dan pelayanan kesehatan sebagai data pendukung berdasarkan hasil wawancara. Rosdewati mendapatkan faktor pengetahuan tidak mempunyai hubungan bermakna dengan status kesehatan gigi dan mulut $(p=0,8)$. Pengetahuan yang cenderung baik kurang memotivasi untuk bersikap dan melakukan tindakan pemeliharaan kesehatan gigi dan mulut, sehingga status kesehatan gigi dan mulut siswa di Kabupaten Langkat relatif rendah.

Pengetahuan responden pada penelitian ini tidak memengaruhi perilaku namun pengetahuan tidak diaplikasikan dalam tindakan mereka dalam sehari-hari. Meskipun responden memiliki pengetahuan yang baik mengenai kesehatan gigi dan mulut, tetapi belum tentu mereka memiliki tindakan yang baik terhadap pemeliharaan kesehatan gigi dan mulut seperti halnya pada masyarakat Paniki Kabupaten Sitaro yang memiliki kesehatan gigi dan mulut yang buruk.

\section{SIMPULAN}

Berdasarkan hasil penelitian dapat disimpulkan bahwa pengetahuan, sikap, dan tindakan masyarakat di Kelurahan Paniki Kabupaten Sitaro tergolong baik 
tetapi status kebersihan gigi dan mulut tergolong buruk.

\section{SARAN}

Diharapkan bagi instansi pemerintah dalam hal ini puskesmas paniki untuk memberikan penyuluhan maupun sosialisasi kepada pihak masyarakat mengenai pentingnya menjaga kebersihan gigi dan mulut. Pengetahuan yang didapatkan akan menjadi suatu dorongan motivasi kepada masyarakat dalam memelihara dan menjaga kebersihan gigi dan mulut.

Bagi masyarakat diharapkan dapat menambah wawasan dan pengetahuan dalam menjaga kebersihan gigi dan mulut yang baik dan dapat berguna juga bagi kesehatan.

\section{DAFTAR PUSTAKA}

1. Depkes RI. Undang-Undang Republik Indonesia No. 36 tentang Kesehatan. Jakarta, 2009.

2. Tirahiningrum P, Nugraeni Y, Sukma CM. Hubungan pola menyikat gigi dengan indeks DMF-T pada siswa kelas VI SD Madrasah Ibtidaiyah Nahdatul Ulama (MINU) Nadla'ul Ulama Kecamatan Blimbing Malang. Malang: Program Studi Pendidikan Dokter Gigi Fakultas Kedokteran Universitas Brawijaya; 2012.

3. Takahindangen $\mathrm{S}$, Mintjelungan $\mathrm{CN}$, Tambunan E. Hubungan pengetahuan kesehatan gigi dan mulut dengan status kesehatan gingiva pada penyandang tunanetra di Panti Tunanetra Manado. eG. 2013;1(2).
4. Notoadmodjo S. Pengantar Pendidikan Kesehatan dan Ilmu Perilaku. Jakarta: Rineka Cipta, 2008.

5. Dean JA, Avery DR, McDonald RE. McDonald dan Avery Penyakit Gigi dan Mulut. Jakarta: EGC, 1978

6. Departemen Kesehatan Republik Indonesia. Riset Kesehatan Dasar. Badan Penelitian dan Pengembangan Kesehatan. Jakarta, 2013.

7. Badan Penelitian dan Pengembangan Kesehatan Departemen Kesehatan Republik Indonesia. Riset Kesehatan Dasar [online]. 2013 [cited 2014 Aug 30]. Available from: http: //www. litbang.depkes.go.id/sites/download/rk d2013/Laporan_Riskesdes2031.pdf

8. Indirawati TN, Magdarina DA. Penilaian indeks DMF-T. Media Litbangkes. 2013;(23)42.

9. McIntosh AR, Kovacevic N, Itier RJ. Increased brain signal variability accompanies lower behavioral variability in development. Research Article. PLOS Computational Biology. PCBI 1000106. Available from: https://doi.org/10.1371/journal.pcbi.1 000106

10. Blais KK, Hayes JS, Kozier B, Erb G. Praktik keperawatan professional: konsep dan perspektif. Jakarta: EGC, 2006.

11. Rosdewati L. Hubungan perilaku pemeliharaan kesehatah gigi dan mulut dengan status kesehatan gigi dan mulut murid SMU di Kabupaten Langkat. Medan: Program Studi Magister Ilmu Kesehatan Masyarakat Universitas Sumatra Utara; 2004. 